\title{
Rehydration kinetics of flour from dehydrated mango kernel
}

\author{
${ }^{1,2 *}$ Das, P.C., ${ }^{1}$ Sattar, S., ${ }^{2}$ Jony, M.E. and ${ }^{2}$ Islam, M.N. \\ ${ }^{1}$ Department of Chemical and Food Process Engineering, Faculty of Mechanical Engineering, Rajshahi \\ University of Engineering and Technology, Rajshahi-6204, Bangladesh \\ ${ }^{2}$ Department of Food Technology and Rural Industries, Faculty of Agricultural Engineering, Bangladesh \\ Agricultural University, Mymensingh-2202, Bangladesh
}

\begin{abstract}
Article history:
Received: 16 July 2018

Received in revised form: 5

August 2018

Accepted: 8 August 2018

Available Online: 15 August 2018
\end{abstract}

\section{Keywords:}

Mango kernel,

Nutritional composition,

Drying kinetics,

Rehydration kinetics,

Activation energy

\section{DOI:}

https://doi.org/10.26656/fr.2017.2(5).210

\begin{abstract}
Mango kernel, a food waste with high nutritional values has been getting a significant focus in food processing, especially in powder form. The study was conducted to compare the rehydration kinetics of processed mango kernel flour (MKF) with wheat flour (WF). In Bangladesh, different mango varieties are available at different time of mango ripening season. Among them, four varieties (Baishakhi, Amrapali, Fazli and Ashwina) were selected to get their component percentage and kernels of the four varieties were analyzed to know about their nutritional values and drying behavior. It was found that mango varieties contained $8.4-12.4 \%$ kernels, $9.80-14.30 \%$ peel, $66.10-72.40 \%$ pulp and $7.50-$ $9.30 \%$ seed coat. The chemical analysis of the kernels revealed that nutrient components varied due to varietal difference. The drying kinetics of the kernels showed that the drying rate constant increased with the increasing of kernels' moisture content, consequently decreased with increasing the duration of ripening season. A comparison of rehydration kinetics between the processed MKF from dehydrated mango kernel and WF at 40, 50 and $60^{\circ} \mathrm{C}$ showed that WF rehydrated quicker than MKF and the activation energy (Ea) values for rehydration were 9.544 and $7.532 \mathrm{KJ} / \mathrm{mol}$ for MKF and WF respectively. The research revealed that nutritious dried flour can be processed from mango kernel which needs more time to rehydrate than WF.
\end{abstract}

\section{Introduction}

Mango (Mangifera indica L.) belongs to the family Anacardiaceae, is one of the most common, popular and important tropical fruits in the world which is well known for its strong aroma, intense peel coloration, delicious taste, and high nutritive value as it has high amounts of vitamin $\mathrm{C}, \quad \beta$-carotene and minerals (Tharanathan et al., 2006). They also reported that the composition of mango varies due to several factors such as cultivation area, maturity conditions, varietal differences etc. The main constituents of the mango pulp are moisture, sugar, vitamins, minerals, organic acids, color and flavor compounds.

According to FAOSTAD (2015), it is the second most traded tropical fruit in the world and also scored fifth among all fruits in terms of total production. From the statistical data of BBS (2015), total 10,18,112 metric tons mangoes were produced in Bangladesh from 61,997 acres land in the year of 2014-2015 which ranked seventh in terms of the highest mango production all over the world.

A full mango consists of its peel, pulp, seed coat, and kernel. The kernel with seed coat is known as seed which represents $10-25 \%$ of the total weight of the whole fruit and the kernel is around $45-85 \%$ or $20 \%$ of whole fruit approximately (Arogba, 1997; Solis and Duran, 2011) but this percentage can vary due to varietal variations, climatic condition, harvesting period etc.

Dhingra and Kapoor (1985) reported that mango kernel has $69.22 \%-79.78 \%$ carbohydrates, $8.35-16.13 \%$ fat, 5.6-9.5\% protein, and $0.35-3.66 \%$ ash. Mango kernel is a good source of carbohydrates $(58-80 \%)$ and protein (6-13\%) and has an attractive profile of essential amino acids and lipids (6-16\%) with rich in oleic and stearic acids (Siaka, 2014).

Sultana (2013) mentioned drying as a modern method of food preservation and defined as a process in which moisture from products is removed to prevent the growth of spoilage microorganism is known for drying or dehydration. Also added that its success largely 
depends on the rehydration properties of the dehydrated products. According to Al-Amin et al. (2015), rehydration is an important process by which a dried material becomes refresh or wet by absorbing water.

Several researchers have reported about the utilization of mango kernel and its components in different foods (Nzikou et al., 2010; Jahurul et al.,2015), however air-drying behavior of different kernels and rehydration kinetics of processed flour can be a matter of research interest.

From the above standpoint of view, the research was conducted to know the component percentage of different mango varieties, to asses to nutritional composition of different kernels, to study the mechanical drying behavior of different mango kernels and to compare the rehydration kinetics of mango kernel flour with wheat flour.

\section{Materials and methods}

\subsection{Materials}

Fresh mangoes (Ashwina, Baishakhi, Amrapali and Fazli) were collected from the mango garden of Chapai Nawabganj and the local market of Rajshahi. Chemicals and solvents used in the study were of AR grade and water was glass distilled unless specified otherwise. Cabinet dryer (Model No.:1816; Modern Laboratory Equipment Co., Inc. New York, U.S.A.) was used for the drying operation.

\subsection{Preparation of mango kernel and component measurement}

Collected mangoes were washed, peeled and pulped to get the mango seed and rinsed immediately. Then, the kernels of the mangoes were separated manually from seeds by cutting and removing the seed coat. The separated peel, pulp, seed coat, and kernel were measured by using the electric balance to know the component percentage of the kernels.

\subsection{Chemical analysis of mango kernels}

Moisture and crude fiber contents were determined according to the method of AOAC (2012). The ash, protein, and fat of the mango kernels were determined using necessary equipment according to the methods described by Ranganna (2005). The quantity of carbohydrate present in the samples was expressed as total carbohydrate and determined by subtracting the measured moisture, ash, protein, and fat from 100 (Pearson, 1976). The total body energy of a human is mainly provided by three groups of nutrients and they are protein, fat, and carbohydrate. Taking this into consideration, the energy content of the samples was calculated by multiplying the specific water factors for protein and carbohydrate as 4 and fat as 9 (Birch, 1980). Triplicate determinations were conducted and the results were presented as mean \pm standard deviation (S.D).

\subsection{Dehydration method}

Cabinet dryer, in which air was blown by a fan passed over a heater was used for the dehydration of mango kernel. Trays of sample were placed in the chamber of the dryer. The moisture content of samples at each time interval was determined by gravimetric method from known initial moisture content. To know the effect of kernel variety on drying kinetics, mango kernels of different varieties were sliced by using slicer into $6 \mathrm{~mm}$ thicknesses and dried at a constant air velocity and specific temperature of $65^{\circ} \mathrm{C}$.

As food dehydration is most frequently assumed to take place by diffusion process, Fick's second law of diffusion can be applied for describing mass transfer during drying. The expression is:

$\frac{\delta M}{\delta t}=\nabla^{2} D_{e} M$

where, $\mathrm{M}=$ Moisture content (dry basis); $\mathrm{t}=$ time; $\mathrm{D}_{\mathrm{e}}=$ Effective diffusion co-efficient.

In order to solve the above unsteady state diffusion equation for one-dimensional transport for the case of initial uniform moisture distribution in the sample and negligible external resistance, appropriate boundary conditions were assumed. The solution for an infinite slab (with thickness $=1$ ) when dried from one major face (Islam, 1980 and Crank, 1975) is:

$M R=\frac{M_{t}-M_{e}}{M_{0}-M_{e}}=\frac{8}{\pi^{2}} \sum_{n=0}^{\infty} \frac{1}{(2 n+1)^{2}} \exp \frac{-(2 n+1)^{2} \pi^{2} D_{e} t}{l^{2}}$

For low $M_{e}$ values and for moisture ratio, $\mathrm{MR}<0.6$, equation (2) reduces to:

$\frac{M_{t}}{M_{0}}=\frac{8}{\pi^{2}} e^{-\frac{\pi^{2} D_{e} t}{l^{2}}}=\frac{8}{\pi^{2}} e^{-m t}$

where, $m=\frac{\pi^{2} D_{e}}{l^{2}}=$ drying rate constant $\left(\mathrm{sec}^{-1} / \mathrm{min}^{-1} / \mathrm{hr}^{-1}\right)$, $D_{e}=$ Effective diffusion co-efficient and $t=$ drying time. Rearranging equation (3) gives:

$\ln M R=\ln \frac{8}{\pi^{2}}-m t$

Consequently, a straight line should be obtained when plotting $\ln (\mathrm{MR})$ versus time $(\mathrm{t})$ and the slope of regression line is the drying rate constant, $\mathrm{m}$.

\subsection{Rehydration kinetics}

Kernels of Baishakhi mango were dried for about 15 hrs at $55-60^{\circ} \mathrm{C}$ for complete removal of moisture and ground to obtain its flour form. The flour is sifted through a 30 mesh size to get fine mango kernel flour 
(MKF) and was compared with wheat flour (WF) to know the rehydration behavior. The rehydration behavior of WF and MKF was measured by combining and modifying the method described by Al-Amin et al. (2015); Apati et al. (2010); Doymaz and Ismail (2010) and Rastogi et al. (2000). Firstly, centrifuge tubes containing distilled water were heated in a controlled water bath up to desired rehydration temperature. When the rehydration temperature was attained, MKF or WF with known moisture content was poured into the centrifuge tubes and rehydrated in the water bath. To get the rehydration kinetic model, the flours were rehydrated at three different controlled temperatures of $40 \pm 1^{\circ} \mathrm{C}$, $50 \pm 1{ }^{\circ} \mathrm{C}$, and $60 \pm 1{ }^{\circ} \mathrm{C}$. The sample and water ratio was maintained at 1:30. When rehydration time completed, the supernatant water of centrifuge's tube was drained off after centrifuging for 5 mins at $3000 \mathrm{rpm}$ and the sediment was weighed again to get the moisture absorbed by the rehydrated materials. The moisture of the rehydrated samples was expressed as $g$ water/g dry sample. The rehydration continued to $30 \mathrm{mins}$ at an interval of 5 mins, then 15 mins interval up to $2 \mathrm{hrs}$ and 30 mins interval up to $4 \mathrm{hrs}$.

\subsection{Statistical analysis}

The results were evaluated for standard deviation, single factor Analysis of Variance (ANOVA) by using Microsoft Office Excel 2013. Figures were prepared using Microsoft Office Excel 2007, Origin 8 and Microsoft Office Visio 2007. Fisher's Least Significant Value (LSD) multiple comparison test procedures were performed to know the significant difference among sample when the F-values of ANOVA reject the null hypothesis by taking $5 \%$ level of significance on accordance to Gomez and Gomez (1984).

\section{Results and discussion}

\subsection{Component distribution of mango kernel}

Components of collected mangoes were separated and the percent distribution of mango fruit component was studied and shown in Table 1. From Table 1, it is seen that kernel content varies from 8.40 to $12.40 \%$ and that early variety Baishakhi gave the highest percentage of kernel content $(12.40 \%)$ as well as seed content $(21.70 \%)$ among the samples (varieties) tested. It is also seen that Amrapali yielded the highest percentage of pulp $(72.40 \%)$ and the Baishakhi gave the lowest percentage of pulp (66.10\%). On the other hand, Ashwina gave the highest peel percentage (14.30\%) while the lowest percentage of peel was given by Amrapali $(9.80 \%)$. A similar study was conducted by Yatnatti et al. (2014) and they found $9.00 \%$ kernel in mangoes. The obtained results were more or less similar to those reported by Dhingra and Kapoor (1985), who reported the seed (seed coat and kernel) content as $18.00 \%$ and kernel content as $10.00 \%$ of total mango fruits. Thus, this study revealed that components of the mango vary from variety to variety.

\subsection{Nutritional composition of mango kernel}

Four types of kernels were analyzed for their nutritional composition and the results are shown in Table 2. Moisture, ash, protein, fat, fiber, total carbohydrate and energy content of four different mango kernels were in the range of $48.79-65.67 \%, 1.08-1.35 \%$, $2.19-4.41 \%, 2.38-5.80 \%, 0.49-0.63 \%, 28.84-39.12 \%$ and $145.50-228.72 \mathrm{Kcal} / 100 \mathrm{~g}$ respectively in wet weight basis (wb) while the corresponding dry weight basis (db) values were $95.27-191.29 \%, 2.50-3.44 \%, 6.38-8.86 \%$, $6.93-11.33 \%, 1.23-1.46 \%, 77.44-83.25 \%$ and $420.89-$ $446.65 \mathrm{Kcal} / 100 \mathrm{~g}$ respectively. The analysis revealed that early variety Baishakhi was rich in protein, fat and carbohydrate content while the latest variety (Ashwina) in moisture and ash content. Nzikou et al. (2010) reported that the moisture content of mango kernel as $45.2 \%(\mathrm{db})$ and Dhingra and Kapoor (1985) found the moisture content as $50.98 \%(\mathrm{db})$ for kernels of Dusheri mango in India. Nzikou et al. (2010), Dhingra and Kapoor (1985), Odunsi (2005) and Changso (2008) found the ash content as 3.2, 2.75, 2.23 and $0.83 \%(\mathrm{db})$ respectively, whereas in mango kernel, $6.36 \%(\mathrm{db})$ protein and $13.62 \%(\mathrm{db})$ fat was found by Nzikou et al. (2010) and Odunsi (2005) respectively. Legesse and Emire (2012) used mango kernel for biscuit production and found $2.51 \%(\mathrm{db})$ fiber and $67.25 \%(\mathrm{db})$ total carbohydrate, while Changso (2008) reported that the crude fiber content of $3.96 \%(\mathrm{db})$ and the carbohydrate of $48.79 \%(\mathrm{db})$ in mango kernel. The observed values are almost similar to that reported by the mentioned authors. The difference of composition among kernel sample and other authors might be due to varietal

Table 1. Component percentage of different mangoes

\begin{tabular}{|c|c|c|c|c|c|c|}
\hline \multirow{2}{*}{\multicolumn{2}{|c|}{ Component }} & \multicolumn{4}{|c|}{$\%$ of whole mango* } & \multirow{2}{*}{$\operatorname{LSD}(\mathrm{P}<0.05)$} \\
\hline & & Baishakhi & Amrapali & Fazli & Ashwina & \\
\hline & Peel $(\%)$ & $12.20 \pm 0.95^{\mathrm{b}}$ & $9.80 \pm 0.78^{c}$ & $10.20 \pm 0.84^{\mathrm{c}}$ & $14.30 \pm 1.03^{\mathrm{a}}$ & 1.22 \\
\hline & Pulp (\%) & $66.10 \pm 1.12^{\mathrm{a}}$ & $72.40 \pm 1.53^{\mathrm{a}}$ & $71.10 \pm 1.45^{\mathrm{a}}$ & $68.6 \pm 1.32^{\mathrm{a}}$ & 41.20 \\
\hline \multirow{2}{*}{ Seed } & Seed coat $(\%)$ & $9.30 \pm 0.63^{\mathrm{a}}$ & $7.50 \pm 0.91^{\mathrm{a}}$ & $8.10 \pm 0.87^{\mathrm{a}}$ & $8.70 \pm 0.67^{\mathrm{a}}$ & 4.74 \\
\hline & Kernel (\%) & $12.40 \pm 0.72^{\mathrm{a}}$ & $10.10 \pm 0.93^{\mathrm{a}}$ & $10.60 \pm 0.89^{\mathrm{a}}$ & $8.40 \pm 0.61^{\mathrm{a}}$ & 5.92 \\
\hline
\end{tabular}

*Average \pm S.D.; $n=5$; Samples having the same superscript do not differ at 5\% level of significance $(\alpha)$. 
Table 2. Nutritional composition of mango kernels

\begin{tabular}{|c|c|c|c|c|c|c|c|c|c|}
\hline \multirow{2}{*}{ Component } & \multicolumn{2}{|c|}{ Baishakhi } & \multicolumn{2}{|c|}{ Amrapali } & \multicolumn{2}{|c|}{ Fazli } & \multicolumn{2}{|c|}{ Ashwina } & \multirow{2}{*}{$\begin{array}{c}\text { LSD } \\
(\mathrm{P}<0.05)\end{array}$} \\
\hline & $\mathrm{wb}^{*}$ & $\mathrm{db}$ & $\mathrm{wb}^{*}$ & $\mathrm{db}$ & $w b^{*}$ & $\mathrm{db}$ & $\mathrm{wb}^{*}$ & $\mathrm{db}$ & \\
\hline $\begin{array}{l}\text { Moisture } \\
(\%)\end{array}$ & $48.79 \pm 1.26^{\mathrm{d}}$ & 95.27 & $52.35 \pm 1.24^{\mathrm{c}}$ & 109.86 & $62.76 \pm 2.49^{b}$ & 168.55 & $65.67 \pm 2.16^{\mathrm{a}}$ & 191.29 & 3.53 \\
\hline Ash (\%) & $1.28 \pm 0.18^{\mathrm{a}}$ & 2.50 & $1.35 \pm 0.22^{\mathrm{a}}$ & 2.83 & $1.08 \pm 0.17^{\mathrm{a}}$ & 2.90 & $1.18 \pm 0.18^{\mathrm{a}}$ & 3.44 & 0.35 \\
\hline Protein $(\%)$ & $4.41 \pm 0.31^{\mathrm{a}}$ & 8.61 & $3.92 \pm 0.22^{b}$ & 8.23 & $3.30 \pm 0.13^{\mathrm{c}}$ & 8.86 & $2.19 \pm 0.11^{\mathrm{d}}$ & 6.38 & 0.39 \\
\hline Fat (\%) & $5.8 \pm 0.10^{\mathrm{a}}$ & 11.33 & $5.11 \pm 0.12^{\mathrm{b}}$ & 10.72 & $4.02 \pm 0.09^{c}$ & 10.80 & $2.38 \pm 0.06^{\mathrm{d}}$ & 6.93 & 0.18 \\
\hline $\begin{array}{l}\text { Crude fiber } \\
(\%)\end{array}$ & $0.63 \pm 0.04^{\mathrm{a}}$ & 1.23 & $0.59 \pm 0.06^{\mathrm{ab}}$ & 1.24 & $0.49 \pm 0.05^{\mathrm{b}}$ & 1.32 & $0.50 \pm 0.06^{\mathrm{b}}$ & 1.46 & 0.10 \\
\hline $\begin{array}{l}\text { Total } \\
\text { carbohydrate } \\
(\%)\end{array}$ & $39.72 \pm 1.47^{\mathrm{a}}$ & 77.56 & $37.27 \pm 1.60^{\mathrm{a}}$ & 78.22 & $28.84 \pm 2.26^{\mathrm{b}}$ & 77.44 & $28.58 \pm 1.87^{b}$ & 83.25 & 3.44 \\
\hline $\begin{array}{l}\text { Energy } \\
\text { (Kcal/100g) } \\
\text { (calculated) }\end{array}$ & $228.72 \pm 4.04^{\mathrm{a}}$ & 446.65 & $210.75 \pm 4.45^{\mathrm{b}}$ & 442.28 & $164.74 \pm 9.07^{\mathrm{c}}$ & 442.40 & $144.50 \pm 8.58^{\mathrm{d}}$ & 420.89 & 13.06 \\
\hline
\end{tabular}

*Samples having the same superscript do not differ at 5\% level of significance $(\alpha)$; wb $=$ wet weight basis (mean \pm standard deviation); $\mathrm{db}=$ dry weight basis (values were calculated only by using the mean wb values).

variation, physicochemical and environmental difference, seasonal effect, harvesting period, pre-harvest and post-harvest condition of mangoes etc.

\subsection{Effect of kernel variety on drying kinetics}

To observe the drying behavior of different mango kernels, $6 \mathrm{~mm}$ kernel slices of four mango varieties were dried in a mechanical (cabinet) dryer at $65^{\circ} \mathrm{C}$. The results were analyzed by using the semi-theoretical equation derived from Fick's law (equation 4) and thus, the values of moisture ratio (MR) versus drying time (hr) were plotted on a semi-log coordinate (Figure 1) and following regression equations were derived:

$$
\begin{array}{ll}
\mathrm{MR}=0.908 \mathrm{e}^{-0.32 \mathrm{t}} & \text { (for Baishakhi) } \\
\mathrm{MR}=1.030 \mathrm{e}^{-0.37 \mathrm{t}} & \text { (for Amrapli) } \\
\mathrm{MR}=1.000 \mathrm{e}^{-0.42 \mathrm{t}} & \text { (for Fazli) } \\
\mathrm{MR}=0.966 \mathrm{e}^{-0.50 \mathrm{t}} & \text { (for Ashwina) }
\end{array}
$$

Where, $\mathrm{t}=$ time in hrs. From the above equations ( 5 to 8 ) and in Figure 1, it is seen that kernel variety had profound influence on drying rate and a general calculation reveals that Ashwina kernel required the lowest time of $4.54 \mathrm{hrs}$ to dry to MR of 0.1 , where Amrapali kernel required $6.23 \mathrm{hrs;}$ Fazli kernels required $5.48 \mathrm{hrs}$ while the highest time of $6.89 \mathrm{hrs}$ was required by Baishakhi kernels to dry to $\mathrm{MR}=0.1$ which is the end of first falling rate period. The observed differences in drying time to specific moisture ratio $(\mathrm{MR}=0.1)$ may be due to differences in physiochemical properties (such as solid/solute, initial moisture content, structure etc.), weather conditions, varieties etc. It may be noted that Baishakhi mango becomes available in the market before the rainy season, Amrapali and Fazli are during the rainy season and Ashwina is after the rainy season. These four mango kernels had different initial moisture content which had an effect on drying rate constant as the higher the initial moisture content, the higher the drying rate constant due to having higher free water. The similar observation was made by Islam (1980).

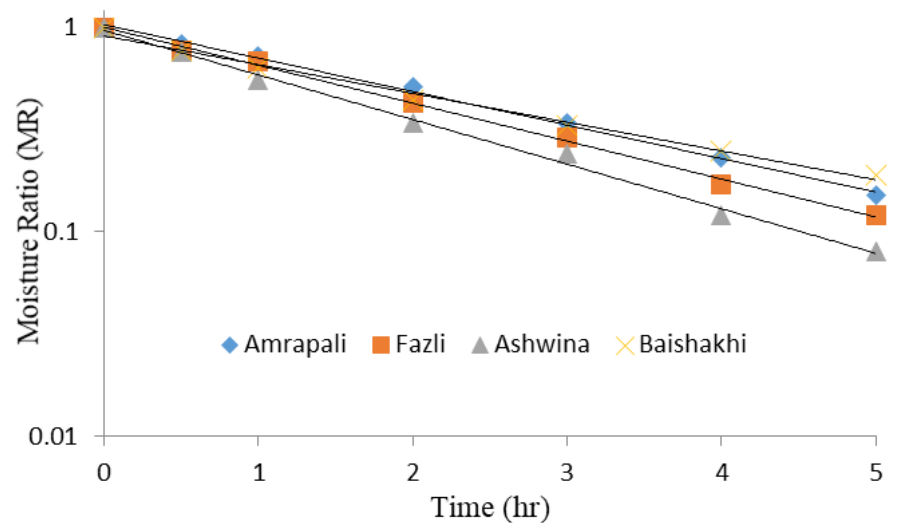

Figure 1. Influence of kernel variety on drying rate at $65^{\circ} \mathrm{C}$ with thickness of $6 \mathrm{~mm}$

\subsection{Comparison of rehydration kinetics between $M K F$ and $W F$}

\subsubsection{Effect of temperature on rehydration behavior and rate constant}

To analyze the effect of temperature on rehydration behavior of MKF and WF, both flours were rehydrated at 40,50 , and $60^{\circ} \mathrm{C}$ and by using Peleg (1988) model where absorption of moisture expressed as ratio (g water/g dry matter) vs time (min) was plotted on linear coordinate (Figure $2(a, b)$ ) and revealed that uptake of the moisture of both flours increased with the increased temperature and time. Athanasia and Konstantinos (2009) observed the same effect in the case of rehydration behavior of dried tomato. As for WF, the increase in moisture content with temperature at each time interval was comparatively higher than MKF and at $60^{\circ} \mathrm{C}$ the degree of moisture uptake was even higher for the WF. This behavior again can be attributed to the difference in ratio of fat, protein, and carbohydrate of the samples and process of gelatinization.

To obtain the rehydration rate constant at different 


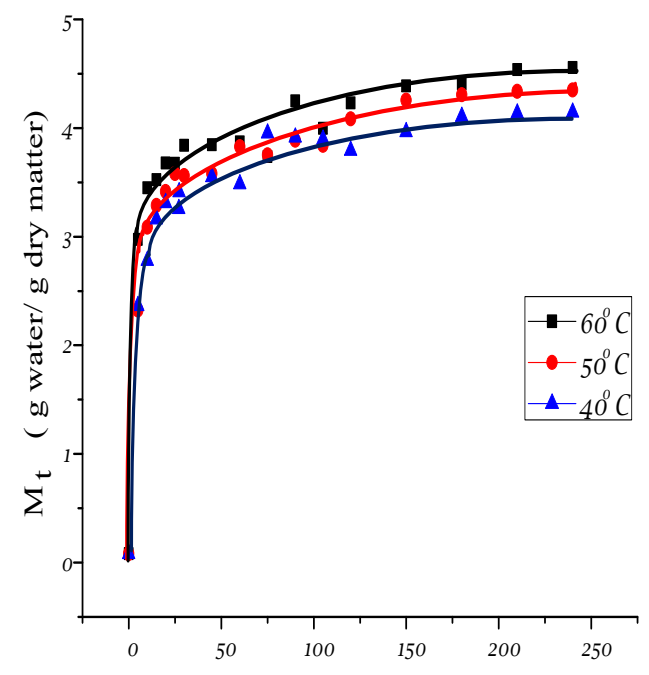

(a) Time (min)

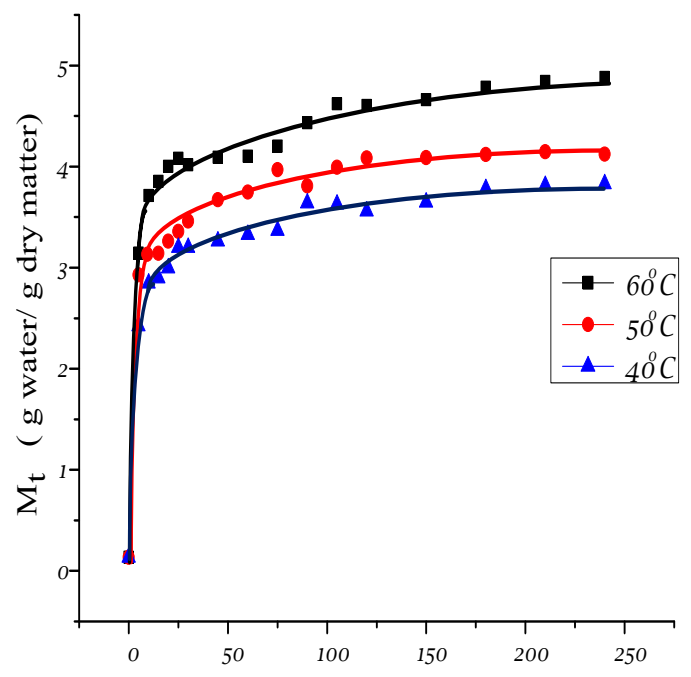

(b) Time (min)

Figure 2. Effect of temperature on rehydration behavior of (a) MKF and (b) WF
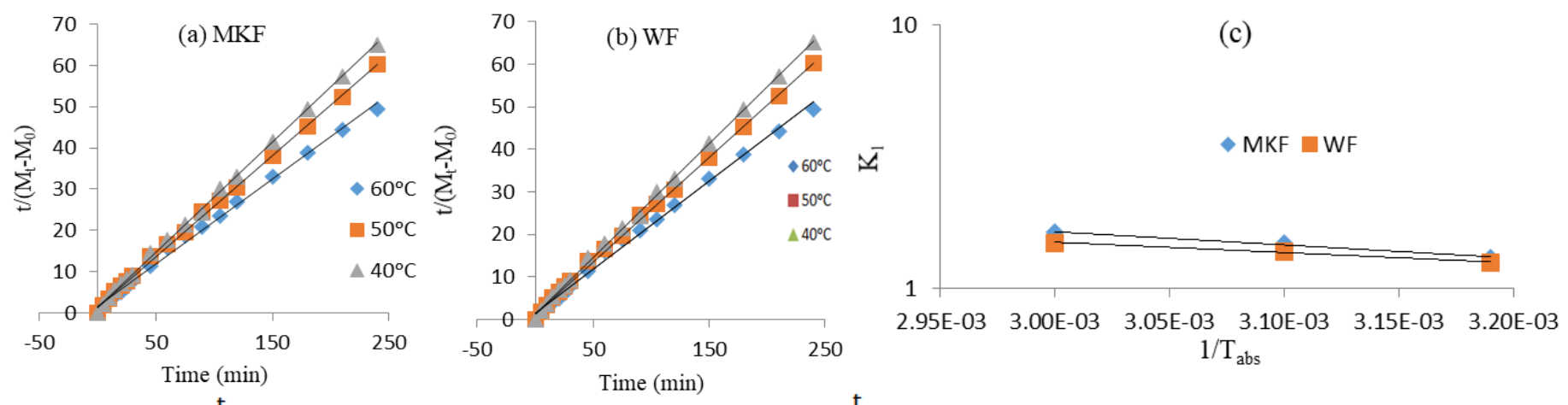

Figure 3. (a) $\frac{\mathrm{t}}{\mathrm{Mt}-\mathrm{M0}}$ vs time plot for MKF using peleg model; (b) $\frac{\mathrm{t}}{\mathrm{Mt}-\mathrm{Mo}}$ vs time plot for WF using peleg model; and (c) Relationship between rehydration rate constant and inverse absolute temperature

temperature, rehydration model described by Peleg (1988) was used and Figure 3(a, b) was obtained for MKF and WF respectively where $\left(\mathrm{t} /\left(\mathrm{M}_{\mathrm{t}}-\mathrm{M}_{0}\right)\right)$ vs time $(\mathrm{t})$ was plotted on linear coordinate and regression analysis gave the following equations (9 to 14):

$$
\begin{array}{ll}
\frac{t}{\mathrm{Mt}-\mathrm{M} 0}=1.629+0.233 \mathrm{t} & \left(\text { for } \mathrm{MKF} \text { at } 60^{\circ} \mathrm{C}\right) \\
\frac{t}{\mathrm{Mt}-\mathrm{M} 0}=1.476+0.232 \mathrm{t} & \left(\text { for } \mathrm{MKF} \text { at } 50^{\circ} \mathrm{C}\right) \\
\frac{t}{\mathrm{Mt}-\mathrm{M} 0}=1.309+0.240 \mathrm{t} & \left(\text { for } \mathrm{MKF} \text { at } 40^{\circ} \mathrm{C}\right) \\
\frac{t}{\mathrm{Mt}-\mathrm{M} 0}=1.486+0.206 \mathrm{t} & \left(\text { for } \mathrm{WF} \text { at } 60^{\circ} \mathrm{C}\right) \\
\frac{t}{\mathrm{Mt}-\mathrm{M} 0}=1.383+0.245 \mathrm{t} & \left(\text { for } \mathrm{WF} \text { at } 50^{\circ} \mathrm{C}\right) \\
\frac{t}{\mathrm{Mt}-\mathrm{M} 0}=1.250+0.267 \mathrm{t} & \left(\text { for } \mathrm{WF} \text { at } 40^{\circ} \mathrm{C}\right)
\end{array}
$$

From Figure $3(a, b)$ and equations (9-14), it is seen that values of rehydration rate constant (min ( $g$ dry matter)/g water) of MKF were found to be $1.309,1.476$ and 1.629 at 40,50 and $60^{\circ} \mathrm{C}$ respectively while for $\mathrm{WF}$, the corresponding values were $1.250,1.383$ and 1.486 The rate constant values (min. $\mathrm{kg}$ dry matter $/ \mathrm{kg} \mathrm{H}_{2} \mathrm{O}$ ) for rehydration of dried tomato were 4.157, 4.177, 4.319 and 4.491 for $25,40,60$ and $80^{\circ} \mathrm{C}$ respectively (Athanasia and Konstantinos, 2009). Souza et al. (2011) reported the values of rehydration rate constant as $2.73,2.61,1.67$ and 1.76 for the powder of freeze-dried beaten pulp, disk, cube and slab sized avocado fruit respectively at room temperature.

\subsubsection{Estimation of Activation energy for $M K F$ and $W F$}

To determine the activation energy for absorption of water by MKF and WF, the rehydration rate constant $\left(\mathrm{k}_{1}\right)$ values were plotted against inverse absolute temperature $(1 /$ Tabs $)$ in a semi-log coordinate and regression lines were drawn (Figure 3 (c)) and the following equations (15 and 16) were developed:

$\begin{array}{ll}\mathrm{K}_{1}=51.27 e^{-1148} / \text { Tabs } & \text { (for MKF) } \\ \mathrm{K}_{1}=22.69 \mathrm{e}^{-906 / \text { Tabs }} \quad(\text { for WF) }\end{array}$

Where, $\mathrm{K}_{1}=$ rehydration rate constant (min. $\mathrm{g}$ dry matter/ $\mathrm{g}$ water), $\mathrm{T}_{\mathrm{abs}}=$ Absolute temperature, ${ }^{\circ} \mathrm{K}$. From the above equations, the activation energy (Ea) for MKF was calculated as $9.544 \mathrm{KJ} /$ mole which was higher than that of WF $(7.532 \mathrm{KJ} / \mathrm{mole})$ and the $\mathrm{K}_{0}$ (min. g dry matter/g water) values are 51.27 and 22.69 for MKF and WF respectively. The Ea value for rehydration of dried spinach was $23.84 \mathrm{KJ} / \mathrm{mol}$ (Dadali et al., 2008). They also reported the $\mathrm{K}_{0}$ value as $0.0075(\mathrm{~s}(\mathrm{~g} \mathrm{db} / \mathrm{g}))$. The 
relatively low Ea value $(1.257 \mathrm{KJ} / \mathrm{mol})$ was reported by Athanasia and Konstantinos (2009) for dried tomato.

\section{Conclusion}

Mango kernel, an important portion of the whole mango can be considered as a supplementary material for food processing. This study indicated that a mango contains around $8.40-12.40 \%$ kernel from the four mango varieties studied. The present study assists to suggest that early variety Baishakhi mango's kernel can be selected for processing into flour or other forms rather than other kernels because of its higher kernel percentage $(12.40 \%)$. The nutritional analysis revealed that the mango kernel is a good source of protein and fat, and can provide a significant amount of energy. To dry faster, Ashwina's kernels are more suitable as this late variety had higher drying rate constant $(0.50 / \mathrm{hr})$ than other three samples. The comparison of rehydration kinetics between MKF and WF concluded that WF rehydrates quickly than $\mathrm{MKF}$ and comparatively more water will require for MKF than WF for a standard dough preparation.

\section{Conflict of Interest}

The authors declare no conflict of interest in this manuscript.

\section{Acknowledgement}

The authors acknowledge with thanks for the financial assistance received to carry out the study from the National Science and Technology (NST) fellowship under Ministry of Science and Technology and also thankful to the Department of Food Technology and Rural Industries of Bangladesh Agricultural University, Bangladesh for supporting other facilities for this study.

\section{References}

Al-Amin, M., Hossain, S. and Iqbal, A. (2015). Effect of Pre-treatments and Drying Methods on Dehydration and Rehydration Characteristics of Carrot. Universal Journal of Food and Nutrition Science, 3(2), 23-28. https://doi.org/10.13189/ujfns.2015.030201.

AOAC. (2012). Official methods of Analysis of Analytical Chemists. $19^{\text {th }}$ ed. USA: Washington DC.

Apati, G.P., Furlan, S.A. and Laurindo J.B. (2010). Drying and Rehydration of Oyster Mushroom. Brazilian Archives Biology and Technology, 53(4), 945-952. https://doi.org/10.1590/S151689132010000400025

Arogba, S.S. (1997). Physical, chemical and functional properties of Nigerian mango (Mangifera indica) kernel and its processed flour. Journal of the Science of Food and Agriculture, 73, 321-328. https:// doi.org/10.1002/(SICI)1097-0010(199703)

73:3<321::AID-JSFA722>3.0.CO;2-4

Athanasia, M.G. and Konstantinos G.A. (2009). Modeling the Rehydration Process of Dried Tomato. Drying Technology: An International Journal, 27 (10), 1078-1088. https:// doi.org/10.1080/07373930903218677

BBS (Bangladesh Bureau of Statistics). (2015). Estimation of major and minor crops. Statistical year book of Bangladesh, p. 199-200. Dhaka, Bangladesh: Statistic division, Ministry of Planning, Government of Peoples Republic of Bangladesh

Birch, G.G., Spencer, M. and Cameron, A.G. (1980). Food science. $2^{\text {nd }}$ ed., p. 29-37. Oxford, UK: Pergamon Press Ltd.

Changso, C. (2008). Study of extraction process, chemical and physic properties of mango seed almond fat CV. Kaew. Bangkok, Thailand: Silpakorn University, MSc Thesis

Crank, J. (1975). The mathematics of diffusion. Oxford, London: Clarenden press.

Dadali, G., Demirhan, E. and Ozbek, B. (2008). Effect of drying conditions on rehydration kinetics of microwave dried spinach. Food and Bioproducts Processing, 86, 235-241. https://doi.org/10.1016/ j.fbp.2008.01.006

Dhingra, S. and Kapoor, A. (1985). Nutritive value of mango seed kernel. Journal of the Science of Food and Agriculture, 36(8), 752-756. https:// doi.org/10.1002/jsfa.2740360817

Doymaz, I. and Ismail, O. (2010). Drying and Rehydration Behaviors of Green Bell Peppers. Food Science and Biotechnology, 19(6), 1449-1455. https://doi.org/10.1007/s10068-010-0207-7

FAOSTAD. (2015). Food and Agriculture Organization of the United Nations. FAO. Retrieved from: http:// faostat.fao.org/site/339/default.aspx.

Gomez, K.A. and Gomez, A.A. (1984). Statistical procedures for agricultural research. $2^{\text {nd }}$ ed., p. 187240. New York: John Wiley and Sons

Islam, M.N. (1980). Use of Solar energy for development of self-stable potato products. Copenhagen, Denmark: Royal Veterinary and Agricultural University, $\mathrm{PhD}$ Thesis.

Jahurul, M.H.A., Norulaini, N.A.N., Zaidul, I.S.M., Jinap, S., Sahena, F., Azmir, J., Sharif, K.M. and Mohd Omar, A.K. (2015). Mango (Mangifera indica L.) by-products and their valuable components: A review. Food Chemistry, 183, 173-180. https:// doi.org/10.1016/j.foodchem.2015.03.046 
Legesse, M.B. and Emire S.A. (2012). Functional and physicochemical properties of mango seed kernels and wheat flour and their blends for biscuit production. African Journal of Food Science and Technology, 3(9), 193-203.

Nzikou, J.M., Kimbonguila, A., Matos, L., Loumouamou, B., Pambou-Tobi, N.P.G., Ndangui, C.B., Abena, A.A., Silou, Th., Scher, J. and Desobry, S. (2010). Extraction and characteristics of seed kernel oil from mango (Mangifera indica). Research Journal of Environmental and Earth Sciences, 2(1), 31-35.

Odunsi, A. (2005). Response of laying Hens and growing broilers to the dietary inclusion of mango (Mangifera indica L.) seed kernel meal. Tropical Animal Health and Production, 37(2), 139-150. https://doi.org/10.1023/ B:TROP.0000048455.96694.85

Pearson, D. (1976). The Dictionary of Nutrition and Food Technology. $5^{\text {th }}$ ed. London: Butterwarth publication.

Peleg, M. (1988). An empirical model for the description of moisture sorption curves. Journal of Food Science, 53(4), 1216-1216. https://doi.org/10.1111/ j.1365-2621.1988.tb13565.x

Ranganna, S. (2005). Hand Book of Analysis of Quality Control for Fruit and Vegetable Products. $2^{\text {nd }}$ ed., p. 1-30. New Delhi: Tata McGraw Hill Publications Company Limited.

Rastogi, N.K., Angersbach, A., Niranjan, K. and Knorr, D. (2000). Rehydration Kinetics of High-Pressure Pretreated and Osmotically Dehydrated Pineapple. Journal of Food Science, 65(5), 838-841. https:// doi.org/10.1111/j.1365-2621.2000.tb13597.x

Siaka, D. (2014). Potential of mango (Mangifera indica) seed kernel as feed ingredient for poultry-a review. World's Poultry Science Journal, 70(2), 279-288. https://doi.org/10.1017/S0043933914000294

Solis, J. and Duran, M. (2011). Mango (Mangifera indica L.) seed and its fats. In Preedy, V.R., Watson, R.R. and Patel, V.B. (Eds.) Nuts and seeds in health and disease prevention, p. 741-748. USA: Academic Press. https://doi.org/10.1016/B978-0-12-3756886.10088-X

Souza, D.S., Pimentel, J.D.R., Prado, M.M., Marques, L.G. and Narain, N. (2011). Rehydration characteristics of freeze-dried avocado (Persea americana). Retrieved from: https:// pdfs.semanticscholar.org/8da8/31cf5b67e3dee16052 a11d2d2db3fee19d22.pdf

Sultana, M. (2013). Studies on the kinetics of air drying and osmotic dehydration of carrot (Daucus carota
L.) and development of mixed product from dried carrot. Bangladesh: Bangladesh Agricultural University, Mymensingh, MSc. Thesis

Tharanathan, R., Yashoda, H. and Prabha, T. (2006). Mango (Mangifera indica L.), "The King of Fruits"An overview. Food Reviews International, 22(2), 95123. https://doi.org/10.1080/87559120600574493

Yatnatti, S., Vijayalakshmi, D. and Chandru, R. (2014). Processing and Nutritive Value of Mango Seed Kernel Flour. Current Research in Nutrition and Food Science Journal, 2(3), 170-175. https:// doi.org/10.12944/CRNFSJ.2.3.10 